autoantibody screen on serum yielded negative results. Intrinsic factor type I (blocking) antibody and parietal cell antibody were not detected in gastric juice. Resting gastric juice $\mathrm{pH}$ was 2 , but difficulties in collection of gastric juice prevented a satisfactory pentagastrin test. A Schilling test showed intestinal malabsorption of vitamin $\mathrm{B}_{12}$ with $3.56 \%$ of free ${ }^{58} \mathrm{CoB}_{12}$ and $3.06 \%$ of intrinsic factor bound ${ }^{57} \mathrm{CoB}_{12}$ excreted into urine over 24 hours. Plasma concentrations of ${ }^{57} \mathrm{CoB}_{12}$ and ${ }^{58} \mathrm{CoB}_{12}$ were assayed between 7 and 11 hours after oral administration, and both showed a peak concentration of $30 \%$ of the predicted normal. Repeated testing for proteinuria (now 19 months after presentation) has yielded negative results. Stool microscopy did not show parasites (including fish tapeworm) or fat globules. Transcobalamin concentration was normal. Urinary indican was low. Barium study of the stomach and small bowel yielded normal results, apart from showing a hiatus hernia.

She has been treated with five $1 \mathrm{mg}$ doses of hydroxocobalamin followed by $1 \mathrm{mg}$ every other month. She made a rapid haematological response, with a normal haemoglobin and blood film one month after starting treatment. All her symptoms have disappeared and she has gained $2500 \mathrm{~g}$ in six months.

\section{Discussion}

The diagnosis of specific malabsorption of vitamin $B_{12}$ was confirmed by the low serum vitamin $B_{12}$, impaired intestinal absorption of vitamin $B_{12}$, the presence of normal gastric acid, and the absence of intrinsic factor antibody and parietal cell antibody in serum and gastric juice. The rapid clinical response to treatment with vitamin $B_{12}$, the lack of steatorrhoea, the normal small bowel barium study, and the low urinary indican make more general malabsorption unlikely, and further investigation was not thought to be justified.

Specific malabsorption of vitamin $\mathrm{B}_{12}$ was described by Imerslund ${ }^{3}$ and has an autosomal recessive inheritance. It is associated with proteinuria in $90 \%$ of cases, ${ }^{4}$ but proteinuria may not occur for 18 months. ${ }^{5}$ Small bowel electronmicroscopy and histology is normal, ${ }^{4}$ and aetiology is unknown. Diagnosis is made by showing intestinal malabsorption of vitamin $B_{12}$ in the absence of general malabsorption.

Doctors tend to stereotype Down's syndrome children, ${ }^{6}$ symptoms of lethargy and mental slowness being interpreted as part of the syndrome. It is important to consider other causes and to be as assiduous in tracking down the diagnosis as one would be for otherwise normal children.

\footnotetext{
References

1 Urban C, Mutz ID, Kaulfersch W. Congenital $B_{12}$ malabsorption without proteinuria. Blut 1981;43:71-5.

2 Conway SP, Gillies DRN, Littlewood JM. Vitamin $B_{12}$ neuropathy in a 6 year old. Arch Dis Child 1984;59:575-6.

${ }^{3}$ Imerslund $\mathrm{O}$. Idiopathic chronic megaloblastic anaemia in children. Acta Paediatr Scand [Suppl] 1960;49:1-115.

${ }^{4}$ Chanarin I. The megaloblastic anaemias. 2nd ed. Oxford: Blackwell Scientific Publications, 1979:434-6.

5 Mohamed SD, McKay E, Galloway WH. Juvenile familial megaloblastic anaemia duc to selective malabsorption of vitamin B $_{12}$. Q J Med 1966:139:433-53.

${ }^{6}$ Hunt S. Stereotyping of children with Down's syndrome. The Journal of Maternal and Child Health 1980;5:328-32.
}

Correspondence to Dr D A Curnock. City Hospital, Hucknall Road, Nottingham NG5 1PB. England.

Received 13 January 1986

\title{
Neonatal malaria and obstructive jaundice
}

\author{
M DAVENPORT
}

Department of Paediatric Surgery, Leeds General Infirmary

SUMMARY A case is presented of transplacental malaria in an infant associated with persistent conjugated hyperbilirubinaemia and liver disease.

Malaria presenting in the neonatal period is a rare disease even in endemic areas.'

\section{Case report}

A female term infant was born in Bradford, England, weighing $2800 \mathrm{~g}$ to Indian parents of a consanguinous marriage who had two other healthy children weighing $5600 \mathrm{~g}$ at term and $1700 \mathrm{~g}$ at 32 weeks. The mother had spent four months of the pregnancy in India, and two days after delivery a 
thick blood smear had shown malarial parasitaemia. This was later confirmed as Plasmodium vivax. There was satisfactory postnatal progress, and the baby was discharged home at 8 days free of jaundice. Consultation was requested at the age of 3 weeks because of feeding difficulties, lethargy, and the occurrence of jaundice.

On admission the infant was small $(3000 \mathrm{~g}:<10$ th centile) and icteric and had a liver edge palpable 1 $\mathrm{cm}$ below the costal margin. The stools were pale coloured and the urine dark. Laboratory findings were as follows: haemoglobin $97 \mathrm{~g} / \mathrm{l}$, white blood cell count $21 \times 10^{9} / 1$ (37\% neutrophils, $54 \%$ lymphocytes, $4 \%$ eosinophils, $5 \%$ others), bilirubin $390 \mu \mathrm{mol} / \mathrm{l}(22.8 \mathrm{mg} / 100 \mathrm{ml})$ with a conjugated fraction of $270 \mu \mathrm{mol} / \mathrm{l}(15.8 \mathrm{mg} / 100 \mathrm{ml})$, alkaline phosphatase activity 491 IU/L (normal range 73-226 IU/l), aspartate aminotransferase activity 235 IU/l (normal range 67-108 IU/l) alanine aminotransferase activity $521 \mathrm{IU} / \mathrm{l}$ (normal range 0-54 IU/I), total protein $53 \mathrm{~g} / 1(5 \cdot 3 \mathrm{~g} / 100 \mathrm{ml}$ ) (normal range $60-80 \mathrm{~g} / \mathrm{l}(6-8 \mathrm{~g} / 100 \mathrm{ml}))$, albumin concentration 26 $\mathrm{g} / \mathrm{l}(2 \cdot 6 \mathrm{~g} / 100 \mathrm{ml})$ (normal range $35-50 \mathrm{~g} / \mathrm{l})$, and globulin concentration $27 \mathrm{~g} / \mathrm{l}(2 \cdot 7 \mathrm{~g} / 100 \mathrm{ml})$ (normal range 21-36 g/l). Serology for toxoplasma, rubella, cytomegalovirus, herpes virus, and hepatitis B were all normal. $\alpha_{1}$ Antitrypsin was $2.8 \mathrm{~g} / \mathrm{l}(280 \mathrm{mg} / 100$ $\mathrm{ml}$ ) (normal range $2 \cdot 1-5 \cdot(\mathrm{g} / \mathrm{l})$, caeruloplasmin 490 $\mathrm{mg} / \mathrm{l}(49 \mathrm{mg} / 100 \mathrm{ml})$ (normal range $200-600 \mathrm{~g} / \mathrm{l}$ ), serum copper $30 \mu \mathrm{mol} / \mathrm{l}$ (normal range 13-27 $\mu \mathrm{mol} / \mathrm{l}$ ), and glucose-6-phosphate dehydrogenase $7.9 \mathrm{IU} / \mathrm{gHb}$ (normal range 8-16 IU/gHb). Sweat test chloride was $16 \mathrm{mmol} / \mathrm{l}(50 \mathrm{mg}$ sweat) (normal range $8-40$ $\mathrm{mmol} / \mathrm{l})$.

A thick blood smear showed heavy parasitaemia due to $P$. vivax, and, therefore, a diagnosis of transplacental malaria was made.

Definitive treatment with chloroquine $(75 \mathrm{mg}$ base daily for four days) and an abbreviated course of primaquine was begun. There is no requirement to treat this form of malaria with an 8-aminoquinoline.

A liver scan (p. butyl iminodiacetic acid labelled with ${ }^{49 m} \mathrm{Tc}$; International CIS Ltd) showed slow hepatic uptake with no significant change in the pattern of radioactivity over six hours, suggesting minimal biliary patency. A Rose Bengal $I^{131}$ test confirmed this impression, with $5 \cdot 3 \%$ of the administered dose being collected in uncontaminated faeces in 48 hours $(<6 \%$ collected suggests extra hepatic biliary atresia).

At six weeks an operative cholangiogram showed a normal extra hepatic biliary tree, therefore excluding surgically correctable biliary atresia. A liver biopsy examination at this time had equivocal features comprising feathery degeneration of hepatocytes, early ductular proliferation and islands of extramedullary haemopoiesis and a polymorphonuclear cell infiltrate. The jaundice was declining (bilirubin $130 \mu \mathrm{mol} / \mathrm{l}(7.6 \mathrm{mg} / 100 \mathrm{ml}$ ), all of which was conjugated), and the infant was discharged home.

The jaundice persisted and the infant failed to thrive. At the age of 4 months the infant was readmitted. The bilirubin concentration was 105 $\mu \mathrm{mol} / \mathrm{l}(6 \cdot 1 \mathrm{mg} / 100 \mathrm{ml})$ (all conjugated) and the alkaline phosphatase activity $1400 \mathrm{IU} / \mathrm{l}$. The infant had moderate hepatosplenomegaly and weighed $5800 \mathrm{~g}(<10$ th centile $)$. The liver scan was repeated and a further percutaneous liver biopsy specimen obtained. This showed progression of the histological features and was more typical of 'neonatal hepatitis' with giant cell transformation, canalicular cholestasis, and persisting portal tract infiltrate of lymphocytes and polymorphonuclear leukocytes.

At last follow up (age 10 months) the infant was still icteric with massive hepatosplenomegaly and below the appropriate weight for age. Bilirubin concentration was $70 \mu \mathrm{mol} / \mathrm{l}(4 \cdot 1 \mathrm{mg} / 100 \mathrm{ml})$, alkaline phosphatase activity $3610 \mathrm{IU} / \mathrm{I}$, albumin concentration $47 \mathrm{~g} / \mathrm{l}$, and cholesterol concentration 3.78 $\mathrm{mmol} / \mathrm{l}(146 \mathrm{mg} / 100 \mathrm{ml})$ (normal range $3 \cdot 5-7 \cdot 5$ $\mathrm{mmol} / \mathrm{l}(135-290 \mathrm{mg} / 100 \mathrm{ml}))$. Repeated investigations have not shown persisting malarial infection.

\section{Discussion}

An association between obstructive jaundice and neonatal malaria was noted by Patwari. ${ }^{2}$ In this Indian study of 10 infants with neonatal malaria an increase in bilirubin concentration was noted in eight $($ mean $167 \mu \mathrm{mol} / \mathrm{l}(9.8 \mathrm{mg} / 100 \mathrm{ml}))$ and in two of these was mainly conjugated. Only six, however, had good evidence of transplacental transmission, and their type of jaundice is not commented upon.

Hepatomegaly is rather less commonly noted than splenomegaly. ${ }^{3}$ All four cases of an American study of imported congenital malaria from South East Asia showed hepatosplenomegaly and jaundice (mean bilirubin concentration $104 \mu \mathrm{mol} / 1(6 \cdot 1 \mathrm{mg} /$ $100 \mathrm{ml})) .{ }^{4} \mathrm{In}$ another report, albeit with a different age range, of 80 children $(<3$ years) with $P$. vivax malaria $63 \%$ had hepatomegaly and $83 \%$ splenomegaly. ${ }^{5}$ It would seem that the younger the age of malarial onset the greater the severity of hepatic damage (and therefore jaundice). In this particular case the presumed lack of passive maternal immunity may be contributory.

The differential diagnosis between 'neonatal hepatitis' and biliary atresia is an important one because surgical relief, if it is to be successful, must be performed early. ${ }^{67}$ The current diagnostic pro- 
cedures did not clarify the nature of the hepatic disease, and even liver biopsy specimens were equivocal, although it should be noted that interpretation of biopsy material can be extremely difficult. $^{8}$

In this case the prognosis is uncertain, and it is still not clear whether the persisting jaundice and liver disease is due to the malarious infection or idiopathic 'neonatal hepatitis'. A chance association between these two rare diseases would seem to be unusual.

I thank Mr J M Beck for allowing me to report on this patient while under his care and for his helpful comments used in its preparation.

\section{References}

1 Logic DE, McGregor IA. Acute malaria in newborn infants. $\mathrm{Br}$ Med J 1970):iii:404.
2 Patwari A, Ancja S. Berry AM. Ghosh S. Neonatal malaria-a clinico-hacmatological profile. Indian Pediatr 1978:15/10:847-9.

${ }^{3}$ Yeager AS. In: Remington JS. KIcin JO, eds. Infectious diseases of the fetus and newborn infant. 2nd ed. Philadelphia: W B Saunders, 1984:563-6.

+ Quinn TC. Jacobs RF, Mertz GJ. Hook EW, Locklsey RM. Congenital malaria: a report of four cases and a review. J Pediatr 1982:101:229-32.

5 Patwari A. Ancja S. Berry AM, Ghosh S. Hepatic dysfunction in childhood malaria. Arch Dis Child 1979:54:139-41.

"Anonymous. Treatment of biliary atresia (Editorial). Br Med J 1979;i:1745-6.

${ }^{7}$ Mowat AP, Psacharopoulos HT, Williams R. Extrahepatic biliary atresia versus neonatal hepatitis. Arch Dis Child 1976:51:763-70.

"Reubner BH. Montgomery CK. Hyperbilirubinacmia and cholestasis in infancy. In: Reubner BH, Montgomery CK, eds. Pathology of the liver and biliary tree. London: John Wilcy and Sons, 1982:141-56.

Correspondence to Mr M Davenport. Plastic and Jaw Department. Fulwood Hospital. Fulwood, Shefficld S10 3TD, England.

Received 31 January 1986 